\title{
船舶バラストタンク内新防食法 (IECOS)の開発
}

\author{
赤 嶺 健一
}

\section{1. 概 要}

1989年アラスカ沿岸でエクソン・バルディズ号20万トン が座礁して, 約 4 万 $\mathrm{kL}$ の原油が流出し, 海洋環境に多大な 被害を与员を。この事故がきっかけで油濁対策が国際世論と なり, タンカーの二重底化が IMO (国際海事機構)により 1992年に法制化された。二重底の内部はバラストタンクと して使用するため，防食処置を施さなければならず，従来の タールエポキシ塗装とした場合, タンク内部が狭隘のため下 地処理および塗装が困難であり，また近年塗装工の減少によ る人件費の高騰など, さまざまな問題が考えられた。そこ で, 塗装に代わる防食法として, 海水中のカルシウムイオ ン，マグネシウムイオンを化合物として，鋼板表面に電気化 学的に沈着させて防食被膜を形成させるェレクトロコーティ ング法のバラストタンクヘの適用化について研究し, 室内試 験, モックアップ試験を経て 3 隻の実船による実機試験を 行い, 新たなバラストタンク内防食法として IHI Electoro Coating System(IECOS : アイェコス)の実用化を達成した. IECOSのバラストタンク内面への適用化により, 塗装工事 に伴ら下地処理から塗装工程まで, いわゆる $3 \mathrm{~K}$ 作業を行 わずに済み, さらに二重底化に伴う防食面積の増加にも対処 することができる，さらにコスト的にも現行法の塗装に比べ 安価となる。市た, 海水に接する鋼構造物一般に適用の可能 性があり, 橋梁·水門·鋼矢板 · 発電設備 (海水導水管内面 $)$ 等適用範囲を拡大することが可能な技術である。

\section{2. 防 食機 構}

『IECOS』は, 海水中に溶存しているカルシウムイオン, マグネシウムイオンを化合物(炭酸カルシウム, 水酸化マグ

石川島播磨重工業株式会社

技術研究所材料研究部腐食・防食グルーブ

Development of New Corrosion Protection System for Ballast Water Tanks (IECOS); Kenichi Akamine (Ishikawajima-Harima Heavy Industries Co., Ltd.)

1998年10月19日受理
ネシウム)として鋼鈑(陰極)表面に析出・付着させ防食被膜 とするものである。図1 亿被膜生成反応の概略図を示す。

『IECOS』に拈ける被膜の断面写真を図 2 に, またその組 成分布を図 3 に示与。

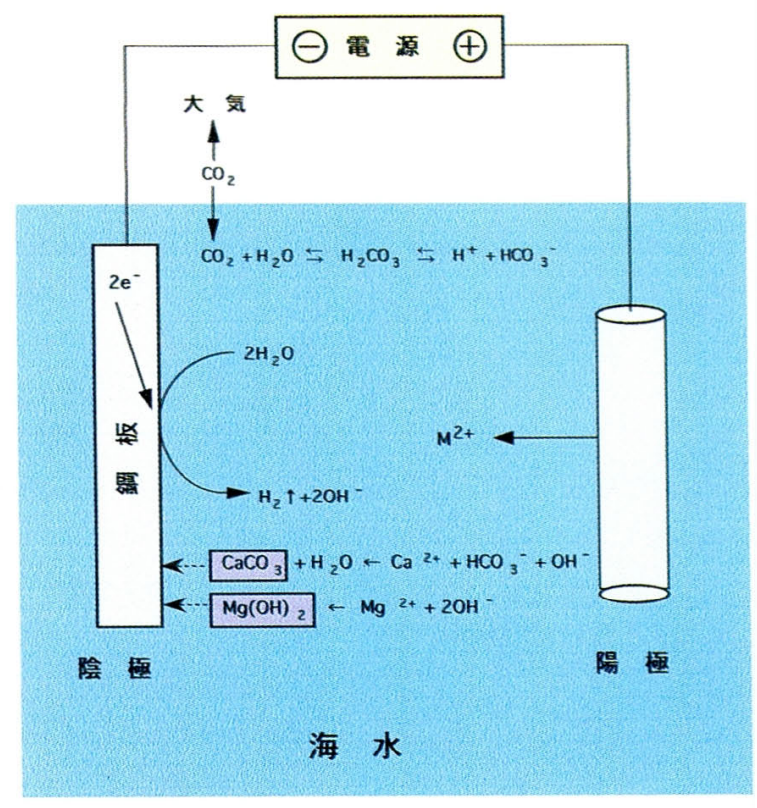

図 1 被膜生成反応の概略図.

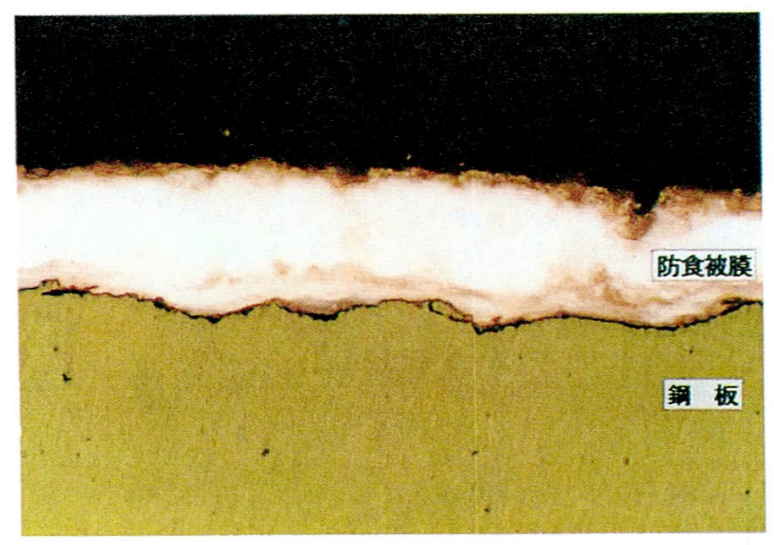

図 2 被膜の断面写真. 


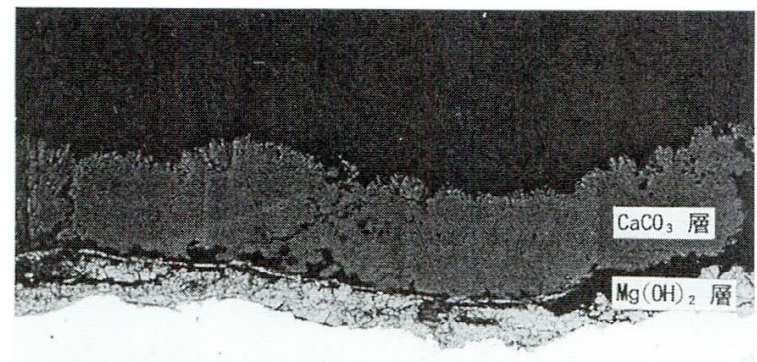

板

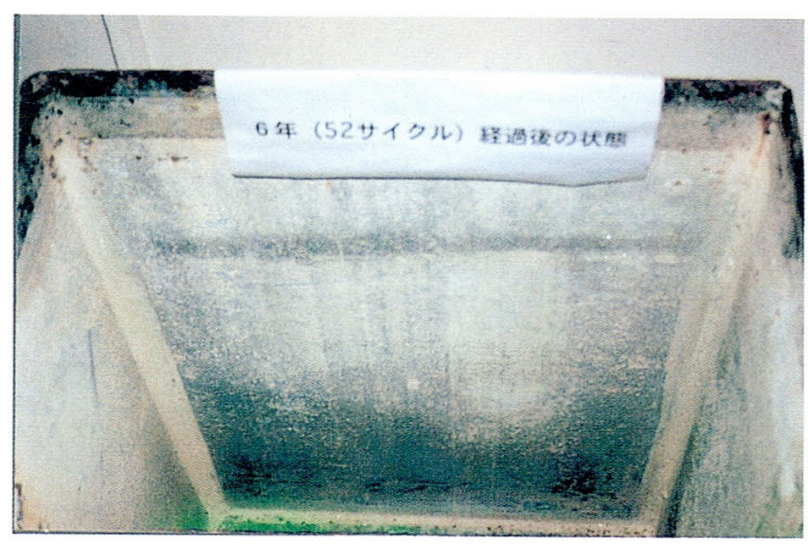

図 4 小型タンクでの耐食性評価 (6 年経過). （図中白色部分が被膜）

図 2 から鋼鈑と被膜との界面には空隙は認められず密着 性の良い被膜であることがわかる。さらに, 図 3 から鋼鈑 近傍には水酸化マグネシウム層, その上に炭酸カルシウム層 が存在し，二層構造となっているのがわかる，すなわち，施 工条件の設定により，このような二層構造被膜を生成させる ことにより, 従来流電陽極法により電気防食を行り際に副生 成物として知られているェレクトロコーティングとは違った 防食性の優れた被膜となる。

水酸化マグネシウムと炭酸カルシウムとではその被膜内 $\mathrm{pH}$ に違いがあり $\left(\mathrm{Mg}(\mathrm{OH})_{2}: \mathrm{pH} 10.0, \mathrm{CaCO}_{3}: \mathrm{pH} 9.0\right), ア$ ルカリ性の高い水酸化マグネシウム層が鋼鈑に接しているこ とにより鋼鈑表面に防食被膜となる不動態被膜が生成される ため優れた防食性を発揮する。しかしながら，水酸化マグネ シウムは海水に溶解しやすい性質があるため長期の防食性は 望めない, そこで, 海水中に飽和に存在し, 溶解しない炭酸 カルシウム層でこの水酸化マグネシウム層を覆らことにより 長期の防食性を達成することができた。このような被膜の利 点は, 被膜生成後に損傷を受けて被膜が欠損した場合でも, 被膜のアルカリ性により自己補修効果があることである.

被膜の防食性の確認試験として, 船舶バラストタンクを想 定してバラストタンクに使用しているショッププライマー (無機亚鉛粉末を含有した一次防錆用塗料)鋼鈑にて作製した 小型タンク $(500 \mathrm{~mm} \times 500 \mathrm{~mm} \times 700 \mathrm{~mm})$ を室内に設置し, 自然海水を用いて漲水21日, 空槽21日：計 42 日（日本〜ペル シャ湾のバラスト条件を想定)を 1 サイクルとした耐食性評 価を 6 年間( 52 サイクル)行い(図 4 参照), 良好な結果を得 た。

さらに, 船舶バラストタンクを模擬した実寸大のタンク (図 5 参照) を暴露状態で設置し, 小型タンク試験と同様の耐 食性試験を行うとともに, 周辺技術の改良 (陽極配置, 温度 の影響，バラスト率の影響等）とフィールドデータの取得を 実施し，実船への適用性を実証した。

\section{3. 船舶バラストタンクへの適用化}

『IECOS』は次の 2 つのステップから成り立っている. 〈ステップ 1: 初期コーティング〉

外部電源法により, 強制的に通電して短期間 (約 7 日間)

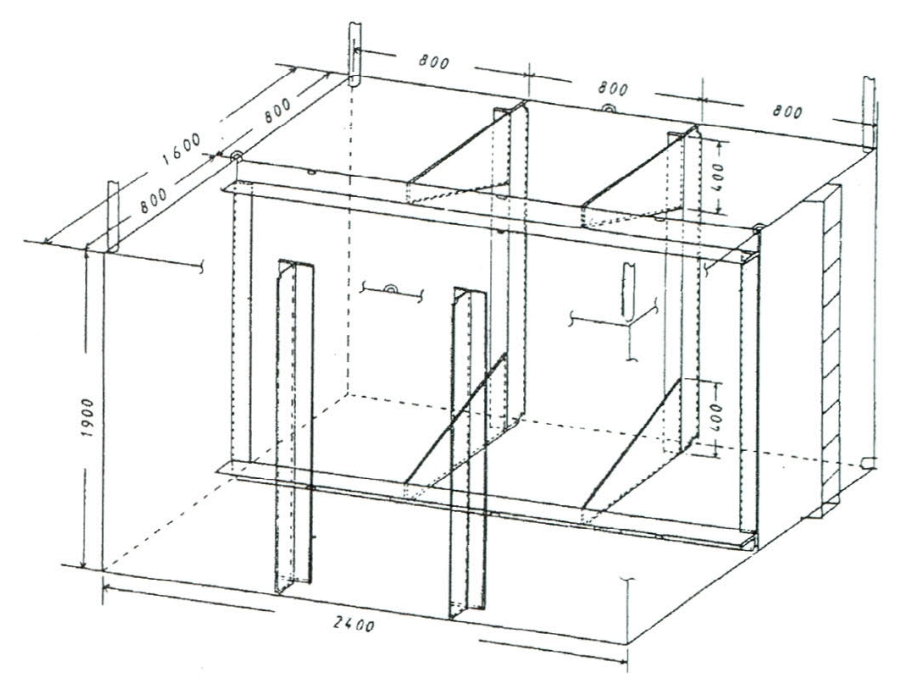

図 5 モックアップ試験体の形状.

で被膜を生成させる。ショッププライマー鋼鈑の場合では, 溶接線, フリーエッヂや建造期間中に溶接, 切断で生じたシ ヨッププライマー欠損箇所等に被膜を生成付着させる.

〈ステップ 2:メンテナンスコーティング〉

流電陽極により防食被膜の増強とショッププライマーの経 年劣化による欠損箇所を自動的に補修する。

その施工法を図 6 に示寸.

室内試験，モックアップ試験において良好な結果を得て， これまで 2 隻の新造バルクキャリアと 1 隻の就航船(船令 9 年のコンテナ船)の二重底タンクに実船適用した。

実船における『IECOS』施工直後のタンク内状況を図 7 に示す。この結果から，これまで塗装による防食法で問題と なっているエッヂ部, コーナー部, 溶接部といった工事が困 難であった箇所に，確実に防食被膜が形成されていることが 確認でき, この点からも本防食法によりタンク内全般に防食 対策が施工できることを実証した．さらに図８に示すように， 30 力月経過後の防食状態も良好であり, 実船への適用性を 実証した。また，実船適用に際して開発した電源システム装 置を図 9 に示す。本装置の特徵は, タンク毎に通電量を設定 することができ, また海水温度や被膜の生成状況をモ二タり 


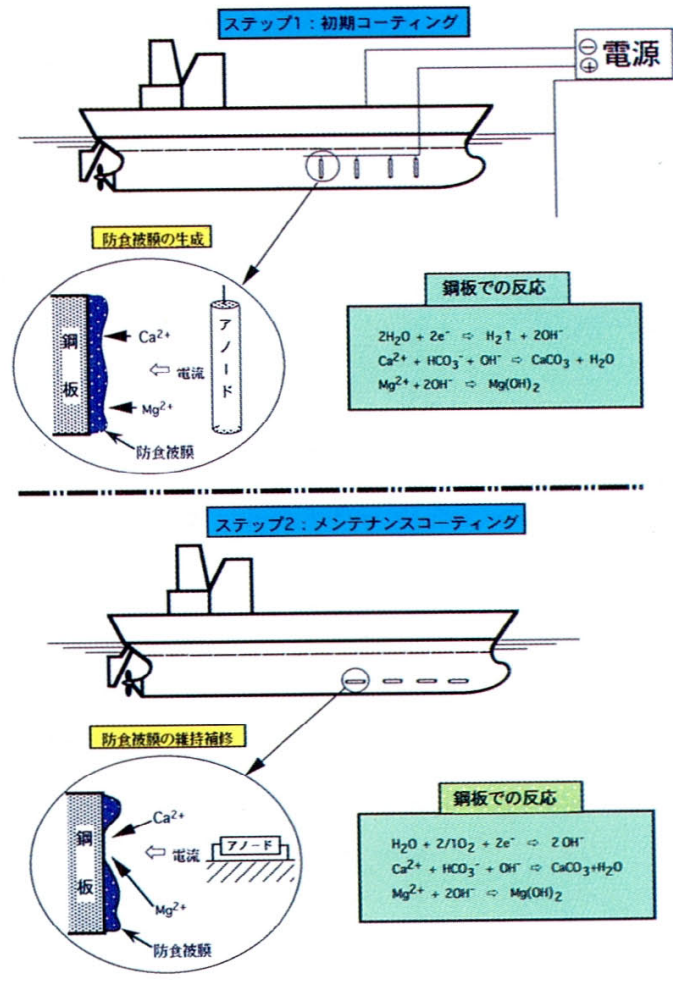

図 6 船舶バラストタンリへの施行法.

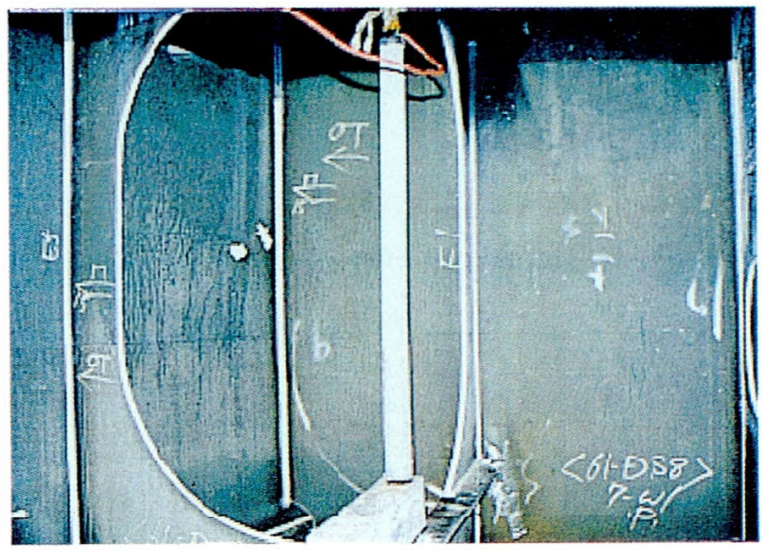

図 7 ステップ 1: 施工直後のタンク内状況.

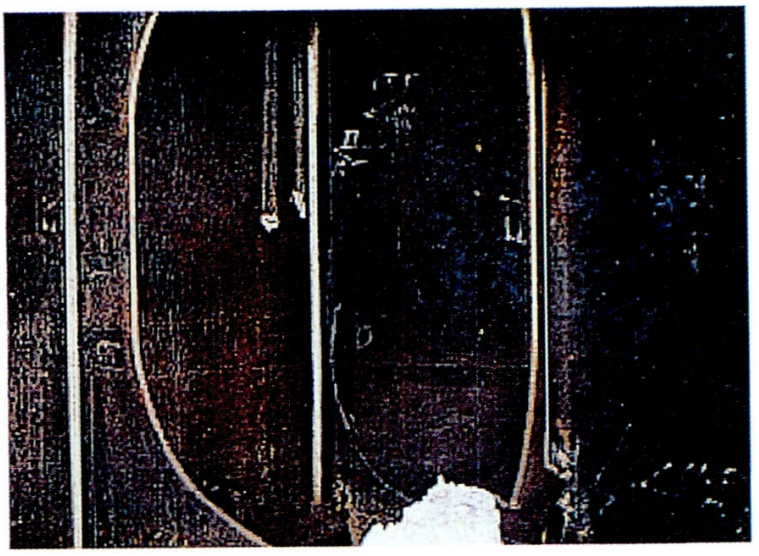

図 8 ステップ 2:30カ月経過後のタンク内状況.

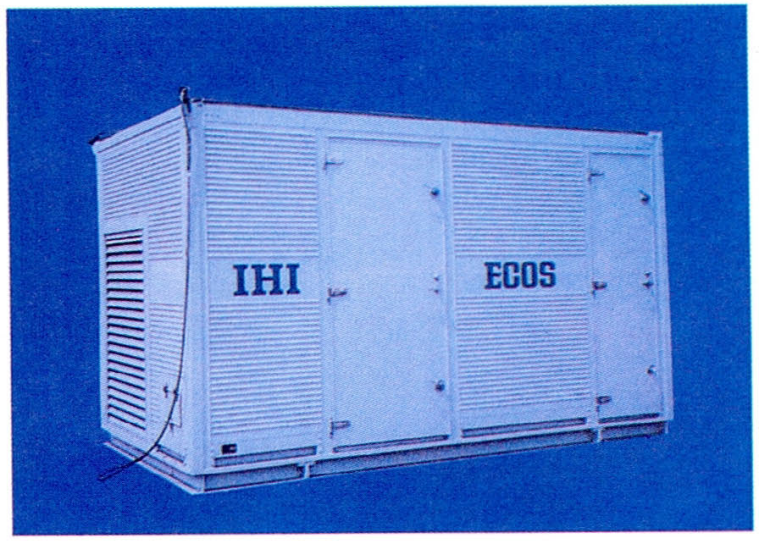

図 9 IECOS 電源システム装置.

ソグするセンサーを装備しており, タンク内噮境に打いて通 電条件を変動させ確実に被膜を生成することがでさる。尚， 本装置で約 $6400 \mathrm{~m}^{2}$ を一度に施工することができる。

\section{4. 技術の適用性}

『IECOS』は船舶バラストタンクに抢ける従来の重塗装に よる防食法を画期的に变更する防食法であり，従来の塗装力 式では構造上工事が困難であった狭隘箇所やエッヂ部，コー ナー部さらには溶接部に確実に防食被膜を形成できる万法で 岁る。李た，本防食法は船舶に限らず海水屯たは汽水に接す る鋼構造物一般に適用でき, 橋梁, 水門, 鋼矢板, メガフロ 一ト，発電設備の海水導水管内面等に適用範用を拡大できる 技術である。現在，ドックゲート内面への適用を実施し，ま た汽水域での水門ゲートへの適用化を計画中である。

\section{5. 経 済 性}

従来法である塗装方式の場合, 足場の組み立て, 下地処 理, 塗装工程が必要であり,また塗装時には湿度の影響を受 けやすく天候によっては塗装がでさない場合もある。一方， 本防食法は, タンク内に陽極設置後, 海水を涱水し通電する ことで施工が可能で工程管理が容易となり, さらに材料費, 人件費も安価となる。また塗装方式の場合， 5 年に一度再塗 装を行ら必要があるが，本防食法の場合メンテナンス用の陽 極を交換するのみであり，初期に設置するアノードによって はメンテナンスフリーとすることもできる、したがって，メ ンテナンスコストを含めたライフサイクルコストでは, 格段 に安価となる。

\section{6. 特 許}

『IECOS』関連特許として13件を申請中でめり, 内 2 件が 審査請求中である。 